\title{
Liability for environmental crimes in the non bis in idem principle context
}

\author{
Sergey Korneev ${ }^{1, *}$, Sergey Pichugin ${ }^{2}$, Tatyana Butenko ${ }^{3}$, Oksana $_{\text {Skorobogatova }}^{3}$, and \\ Yulia Kokambo ${ }^{3}$ \\ ${ }^{1}$ Academy of the Federal penitentiary service of Russian Federation, 1 Sennaya str., Ryazan, 390000, \\ Russia \\ ${ }^{2}$ Vladimir Law Institute of the Federal Penitentiary Service of Russia, 67, Bolshaya Nizhegorodskaya \\ str., 600020, Vladimir, Russia \\ ${ }^{3}$ Amur State University, 21, Ignatievskoe highway, Blagoveshchensk, 675027, Russia
}

\begin{abstract}
In light of the social need for the humanization of criminal policy, annually confirmed by the supreme authorities of the state, the specialized literature has updated the topic related to the prohibition of double jeopardy (it protects against a second prosecution for the same offense after acquittal, against a second prosecution for the same offense after conviction and against multiple punishments for the same offense). This issue is analyzed by researchers in the context of the «non bis in idem» principle, which has received regulation both in the norms of national and international law. An analysis of the law enforcement practice of the judiciary in considering criminal cases on the fact of violation of public relations in the field of environmental protection (Chapter 26 of the Criminal Code of the Russian Federation) indicates the permissibility of double, and in some cases triple, intersectoral liability of the perpetrator of crimes. It seems that the legitimacy and the possibility of deprivation and legal restrictions in relation to citizens have been found guilty of committing a crime and who have served the sentence imposed by the court in full does not correspond to the principle of "non bis in idem", which actualizes the chosen research topic.
\end{abstract}

\section{Introduction}

According to the encyclopedic and lexical interpretation, the principle "Non bis in idem" literally translates as «not twice for the same thing» [1, p. 133, 486, 502, 675]. In this connection, first of all, the emphasis is placed on the prohibition of bringing a person to criminal responsibility twice for the same crime.

Principles «Non bis in idem» are reflected in specialized sources of international law, in particular:

- «no one should be tried, sentenced or punished again for a crime for which he has already been finally convicted or acquitted in accordance with the law and the criminal

\footnotetext{
*Corresponding author: kornei_lam@mail.ru
} 
procedure law of each country» (paragraph 7 of article 14 of the International Covenant on Civil and Political Rights) [2];

- «no one should be repeatedly tried or punished in a criminal procedure under the jurisdiction of the same state for a crime for which he has already been acquitted or convicted in accordance with the law and the criminal procedure rules of this state» (paragraph 1 of article 4 record No. 7 to the Convention for the Protection of Human Rights and Fundamental Freedoms) [3].

In the domestic criminal law, the principle «Non bis in idem» corresponds to the principles of justice (Art. 6 of the Criminal Code of the Russian Federation) and humanism (Art. 7 of the Criminal Code of the Russian Federation), as well as the requirement to economize on criminal repression, which is absent in the Criminal Code of the Russian Federation, but is actively discussed in the doctrine of criminal law [4].

So, according to the cross-sectoral, international principle «Non bis in idem», a person cannot be criminally liable twice for committing the same act prohibited by criminal law. In the light of this, the legal mechanism of imposing subsidiary encumbrances as punishment in relation to a person, convicted of a crime and who has served a measure of state coercion imposed by a court in full, is being exceptionable. As a rule, the considered deprivations and legal restrictions are implemented within the framework of criminal liability in the form of a criminal record or in the form of administrative supervision.

The purpose of the study is to assess the admissibility of the occurrence of deprivations and legal restrictions in relation to citizens found guilty of a crime and who have served the sentence imposed by the court in full. To solve this goal, it is necessary to solve the following tasks:

- to analyze examples from judicial practice, in particular, on bringing a person to criminal liability for environmental crimes;

- to study the extent of deprivations and legal restrictions imposed on the perpetrator of the crime;

- to determine the essence of both criminal law and related institutions: punishment, conviction, administrative supervision;

- to scientifically substantiate the social need for the inadmissibility of additional encumbrances in relation to a person who has served a criminal sentence in full.

\section{Methods}

In the specialized literature, there is a sufficient number of studies devoted to both the general characteristics of environmental crimes, their classification [5], and the prohibition of the double jeopardy within the framework of the «non bis in idem» principle. Some scholars consider this semi-phenomenological idea through the prism of criminal law [6], as well as related legal branches: administrative [7], criminal procedural [8], fiscal [9], etc. Despite the multifaceted intersectoral coverage of the stated problem, it seems that the issue in the field of criminal law concerning the legitimacy of the occurrence of deprivations and legal restrictions in relation to a person convicted of a crime under Art. 216 of the Criminal Code of the Russian Federation (Violation of safety rules during construction or other work) is still unresolved. The same issue is found in relation to a person who has served the full sentence imposed by the court in the context of the principle «non bis in idem».

In the course of this research, various general scientific and private scientific methods of cognition were consistently applied. 


\section{Results}

The conducted research allowed us to come to the following conclusions:

1. Over the past three years, the number of people convicted of environmental crimes amounted to 15,782 people (Fig. 1).

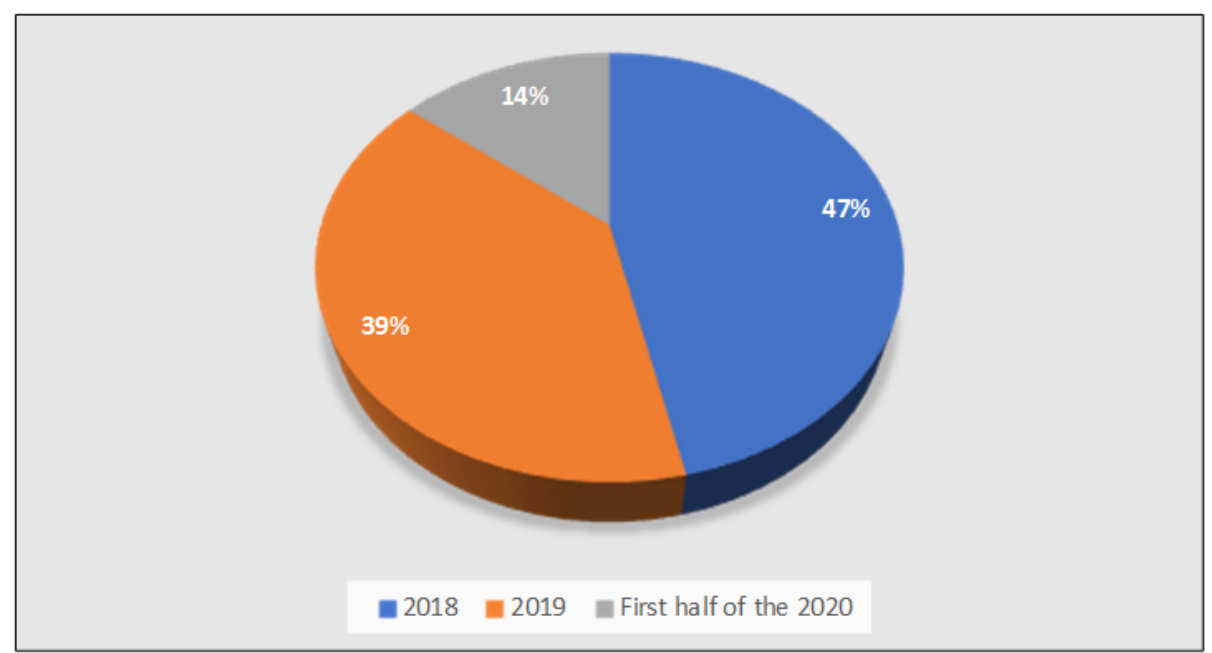

Fig. 1. Number of persons prosecuted for environmental crimes in 2018-2020.

2. Punishment in the form of imprisonment for environmental crimes was applied 855 times (Fig. 2)

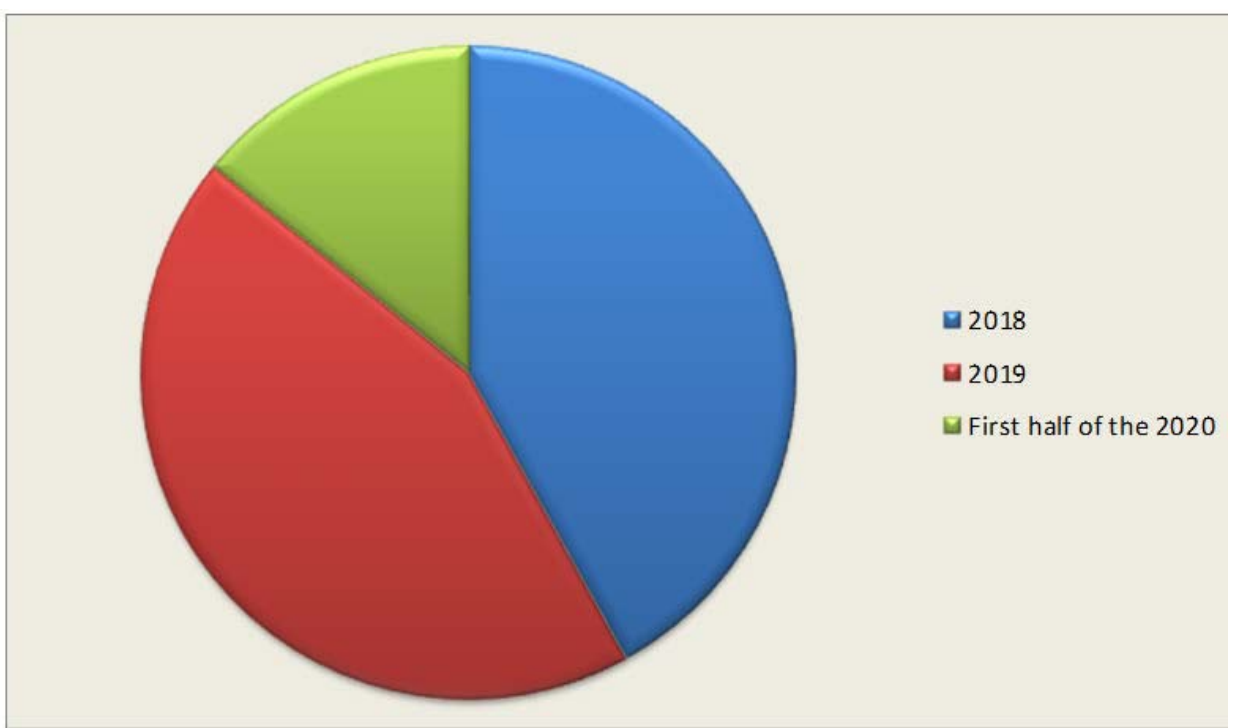

Fig. 2. The number of cases of imprisonment punishment for environmental crimes in 2018-2020.

3. A de jure conviction is a special legal status of a person who has been found guilty of a crime and has served a term of punishment established by a court (measures of state coercion). De facto, a criminal record is identified with a prolonged type of criminal punishment, which takes on the form of additional punishment in the event of a new act prohibited by the criminal law, which contradicts the principle of justice (Article 6 of the 
Criminal Code of the Russian Federation) and the general principles of sentencing (Article 60 of the Criminal Code of the Russian Federation).

4. Administrative supervision, an institution of the branch of law of the same name, in its essence is a measure of criminal liability, since the deprivations and restrictions experienced by the supervised person are identified with the volume of encumbrances of a criminal-legal nature experienced by the convict in the framework of the implementation of certain types of punishment, conditional conviction, parole.

5. It seems that deprivations and restrictions, subsidiary in relation to punishment, prolonging the bulk of state repression against a person found guilty of committing an environmental crime and who has served the sentence imposed by the court in full contradict the principle «non bis in idem».

\section{Discussion}

Responsibility for environmental crimes is regulated by the criminal legislation of the Russian Federation (hereinafter referred to as the RF). The maximum term of punishment in the form of imprisonment, provided for by the sanction of Article 26 of the Criminal Code of the RF, is ten years (part 4 of Art.261 of the Criminal Code of the RF), therefore, the act in question refers to a crime of small or medium gravity. At the same time, the analysis of judicial practice indicates the possibility of the emergence of subsidiary, independent in relation to punishment, deprivations and legal restrictions.

Thus, the Uglichsky District Court of the Yaroslavl Region, having considered the administrative claim of the head of the penal colony 3 of the Federal Penitentiary Service of Russia for the Yaroslavl Region against citizen K. about the establishment of administrative supervision, came to the conclusion that it was satisfied. During the trial, the judge took into account the following legally significant facts. Convicted $\mathrm{K}$. served the full sentence appointed by the court, however, in the process of its execution the convicted:

- was not employed, had no desire to work;

- reacted poorly to the educational work being carried out;

- did not participate in the social life of the detachment and the colony;

- did not deserve any rewards;

- was repeatedly subjected to strict penalties for violations of the established procedure for serving a sentence, all penalties have not been lifted and not extinguished to date;

- was recognized as a malicious violator of the established order of serving the sentence.

Thus, the court concluded that the convicted person did not take the path of correction [10].

The considered, as well as other examples from judicial practice, testifies to the permissible possibility of establishing additional deprivations and legal restrictions in relation to a person who has served his sentence in full within the framework of the implementation of a criminal record and administrative supervision.

From the moment the court's conviction is entered into until the conviction is removed or canceled, the person experiences deprivation of liberty and legal restrictions of an intersectoral nature, since the latter affect public relations, regulated by both federal and criminal, penal legislation. Let us dwell on the essence of the stated restrictions in more detail.

So, criminal legal encumbrances find their expression in:

- qualification of a number of crimes (part 5 of article 131, part 5 of article 132, part 6 of article 134, part 5 of article 135, article 2042 of article 2641 of the Criminal Code of the RF, etc.);

- establishing the recidivism of crimes (Art. 18 of the Criminal Code of the RF); 
- release from criminal liability and punishment (part 1 of article 75, article 76, part 1 of article 761, article 762, article 801 of the Criminal Code of the RF);

- extending the retrospective force of the criminal law to the convicted person (part 1 of article 10 of the Criminal Code of the RF).

In accordance with the criminal-executive legislation, persons who have served their sentences bear obligations and enjoy the rights that are established for citizens of the Russian Federation, with the restrictions provided for by federal law for persons with a criminal record (Article 179 of the Criminal Code of the RF). The restrictions of the considered branch of law are expressed in;

- the separation of convicts (Art. 80 of The Executive Penal Code of the RF);

- establishing the type of correctional institution and the conditions for serving the sentence directly in it (Art. 74, Art. 87 of The Executive Penal Code of the RF);

- changing the type of correctional institution (Art. 78 of The Executive Penal Code of the RF);

- the establishment of administrative supervision (173.1 of The Executive Penal Code of the RF), etc.

The general legal encumbrances provided for legislation play a colossal role in the current society. In particular, a person with an outstanding or unexpunged criminal record:

- has difficulties in finding a job, which means stable, average earnings, living space, socially useful ties as factors of normal life are lost;

- does not have the right to find a job in the state or law enforcement services, in the sphere of pedagogy, culture, sports, social protection and arts, is limited in electoral rights;

- experiences moral and internal limitations, experiences, infringement on the part of others, society as a whole, which in most cases pushes him to the wrong, criminal path.

A number of the designated encumbrances of a general legal nature are not established according to the differentiation of the terms of conviction, but are a lifelong «stigma» of the person who committed the crime.

We believe that the considered inter-sectoral encumbrances in their essence can be compared with the volume of restrictions on certain types of punishment (for example, restriction of freedom (Article 53 of the Criminal Code of the RF)). In this regard, it seems that for the commission of the same act prohibited by the criminal law, a person is subjected to double repression by the state, which is not entirely consistent with the provisions of the criminal law on the principle of justice (Article 6 of the Criminal Code of the RF) and the general principles of appointment punishment (Art. 60 of the Criminal Code of the RF).

Administrative supervision is a measure of state coercion ordered by a court decision. Administrative supervision is applied for preventive purposes to a person released from places of confinement and having an unreleased or outstanding conviction for certain types of crimes, and consists in the deprivation and restriction of the rights and freedoms of this person provided for by law [11, p. 72].

The essence of administrative supervision is manifested in the deprivations and restrictions (including of a constitutional nature) determined by the legislation of a person released from places of detention and having an unexpunged or outstanding conviction for committing crimes defined by the current legislation, which find their expression in a mandatory appearance before a supervisory authority, as well as the prohibition of:

- staying in certain places;

- visiting places of holding mass and other events and participating in these events;

- staying outside the place of residence at a certain time of the day;

- leaving the territory established by the court (Article 4 of the Federal Law) [12]. 
The stated restrictions are established for preventive purposes, as well as for the purpose of providing individual preventive exposure, protecting state and public interests (Article 2 of the Federal Law) [12].

It seems that the variability and content of the declared restrictions are similar to the duties, the purpose of which is provided for by the criminal legislation in relation to a conditionally convicted person (part 5 of article 73 of the Criminal Code of the RF), a person released on parole from serving a sentence (part 2 of article 79 of the Criminal Code of the RF), a person who has been sentenced to restraint of freedom (part 1 of article 53 of the Criminal Code of the RF).

So, when a person commits a grave or especially a crime, the court may impose restriction of freedom as an additional type of punishment. Within the framework of the latter, after being released from places of imprisonment, the convicted person experiences restrictions determined by the norms of the criminal law (part 1 of article 53 of the Criminal Code of the RF), at the time of the end of the implementation of which administrative supervision is established. It seems that the essence of criminal legal encumbrances does not fundamentally change, in this connection, we can talk about the prolongation of the deprivations and legal restrictions of a person who has an unexpunged and outstanding conviction.

A similar process is observed when a person evading administrative supervision is prosecuted (Art. 3141 of the Criminal Code of the Russian Federation). Thus, the Elabuga City Court of the Republic of Tatarstan, having considered the materials of the criminal case against Sh., Accused of committing a crime under Part 2 of Art. 3141 of the Criminal Code of the Russian Federation, came to the conclusion that a sentence of imprisonment was imposed. When formulating the final decision, the court considered the confessions of the accused, the circumstances of the case, his marital status and considered it possible to apply the requirements of Art. 73 of the Criminal Code of the Russian Federation. Thus, the court sentenced Sh. To be found guilty of committing a crime and sentenced him to imprisonment for a term of six months conditionally with the imposition of certain duties: to appear in a specialized state body exercising control over the behavior of conditionally convicted persons and not to change his permanent place of residence without notifying [13]. From the above, as well as other examples of judicial practice, it follows that the deprivations and restrictions experienced by the convicted person within the framework of administrative supervision, with the appointment of imprisonment, conditionally fundamentally do not change.

Administrative supervision can be established during the period when a person fulfills obligations related to parole from places of deprivation of liberty [14]. In addition, according to the current legislation, administrative supervision is established in relation to a person who, during the period of serving a sentence in places of deprivation of liberty, was recognized as a persistent violator of the established procedure for serving a sentence (Article 3 of the Federal Law). According to the criminal-executive legislation, if within one year from the date of imposition of a penalty a new one is not applied, the convicted person is considered to have no penalty (part 4 of article 59 of the Criminal Code of the $\mathrm{RF}$ ). In view of this, according to general rules, this fact is not a reason, an obstacle for the court to refuse to satisfy parole from serving a sentence if, for example, a person has committed a malicious violation of the established procedure for serving a sentence at the beginning of the execution of the sentence imposed by the court. The key factors in solving this issue are the behavior of the convict, his attitude to study and work, the available incentives and penalties, attitude to the committed act, partial or full compensation for the damage caused by the crime or other mitigation of harm, the conclusion of the administration of the institution of the penal system on the appropriateness of the application of an early release (part 41 of article 79 of the Criminal Code of the RF). 
Proceeding from this, the range of duties imposed by the court on a conditionally released person after the end of the probationary period can be prolonged, but already within the framework of administrative supervision.

\section{Conclusion}

The deprivations and restrictions experienced by the convicted person in the framework of the implementation of a criminal record are not included in the scope of punishment, just as they are not in view of the fact that the list of types of punishment is exhaustive and is not subject to broad interpretation. We believe that the legislative boundary between the institutions of punishment and conviction, considering the doctrinal analysis of the essence of deprivation and restrictions implemented within the framework of the categories under consideration, acquires a formal character. It seems that their application is carried out on the same material and formal grounds. Consequently, the punishment imposed by the court is disproportionate to the social danger of the crime committed and the identity of the perpetrator, which contradicts the provisions of the norms of the criminal law (Art. 6, Art. 60 of the Criminal Code of the RF).

In essence, the deprivations and restrictions experienced by a person in the framework of the implementation of criminal liability are identical to the restrictions imposed in the establishment of administrative supervision, and therefore, we can only talk about their prolongation. At the same time, the implementation of administrative supervision contradicts the principle of Non bis in idem, since for the commission of the same act prohibited by the criminal law, the convicted person experiences double repression from the state.

\section{References}

1. I.Kh. Butler, Latin-Russian dictionary. About 50,000 words ("Russian language", M., 1976)

2. International Covenant on Civil and Political Rights. United Nations official website, https://www.un.org/ru/documents/decl_conv/conventions/pactpol.shtml

3. Protocol No. 7 to the Convention for the Protection of Human Rights and Fundamental Freedoms, https://docs.cntd.ru/document/901868012

4. V.M. Stepashin, Economy of repression as a principle of criminal law and its implementation in the appointment of measures of criminal responsibility: dis. doc. jurid. sciences (Omsk, 2019)

5. O.P. Builov, V.I. Brusentsev, International student scientific bulletin 2-3, 282-283 (2015)

6. G.V. Ignatenko, Russian legal journal 1, 75-87 (2005)

7. K.A. Bedareva, Contentus 5, 39-47 (2019)

8. Yu.V. Anokhin, V.Yu. Belitsky, Fighting crime: theory and practice: Abstracts of the VII International Scientific and Practical Conference, 233-236 (2019)

9. K.I. Filippova, Criminal law: development strategy in the XXI century: mat. XII int. scientific and practical conf. (Moscow, 2015)

10. Decision No. 2A-665/2018 2A-665/2018 of June 19, 2018 in case No. 2A-665/2018, Archive of the Uglich District Court of the Yaroslavl Region, https://sudact.ru/regular/doc/JjMXoZpYVZY1/ 
11. S.A. Korneev, Bulletin of the Volgograd Academy of the Ministry of Internal Affairs of Russia 1, 69-73 (2021)

12. On the administrative supervision of persons released from places of deprivation of liberty: Federal Law of 06.04.2011 No. 64-FZ, http://www.kremlin.ru/acts/bank/32939/page/1

13. The verdict of July 30, 2020 in criminal case No. 1-265. Archive of the Yelabuga City Court of the Republic of Tatarstan (2020) https://sudact.ru/regular/doc/ITQ9D5pjlYxv/

14. Rossiyskaya Gazeta, On some issues arising when the courts are considering cases of administrative supervision of persons released from places of detention: Resolution of the Plenum of the Supreme Court of the Russian Federation of May 16, 2017 No. 15 (2017)

15. V.F. Lapshin, S.A. Korneev, R.V. Kilimbaev, IOP Conference Series: Materials Science and Engineering 1001, 012144 (2020) DOI: 10.1088/1757$899 X / 1001 / 1 / 012144$ 